\title{
Starting the emergency process: some reflections on presidential prerogatives in South Africa and Cameroon in time of turmoil
}

\author{
By Gerard Emmanuel Kamdem Kamga*
}

\begin{abstract}
The study investigates and entails a crossed analysis of the legal and constitutional processes through which a state of emergency and a state of siege are brought into being within the contexts of Cameroon and South Africa. In both countries, a presidential act is required to enforce these institutions. However, the significant fact is that the status and the legal regime of such an act are different and lead to some major consequences on human rights and the rule of law. In the case of Cameroon, the presidential act declaring a state of emergency or a state of siege is an Act of state whereas in the case of South Africa, it is an Act of Parliament. The latter is subject to judicial review and parliamentary appreciation whereas the former is linked to the idea of raison d'état and is a completely presidential matter.
\end{abstract}

\section{A. Introduction}

The paper investigates and entails a crossed analysis of the legal and constitutional processes through which emergency regimes are brought into being in Cameroon and South Africa. The comparison of both countries owes to their common colonial experience and the close similarity of their legal systems. Indeed both systems are strongly characterised by a mixed legal system, meaning that as a result of historical developments and colonialism, a civilian legal system has been merged with those of common law and indigenous customary law.

Emergency regimes are a set of exceptional measures allowing states to legally suspend law and infringe the freedoms and human rights of the governed. They generally refer to a state of emergency, a state of exception and a state of siege. Generally with a view of protecting the state from any potential danger, most constitutions around the world provide for some circumstances namely war, insurrection, invasion and natural cataclysm that may threaten the state's existence. In such circumstances the state generally infringes its own rules as the enforcement of a state of emergency involves concentration of powers and government by decree, restriction of the movement of person and property to administrative

* Postdoctoral Fellow, Department of Jurisprudence, University of Pretoria. E-mail: gerard.emmanuel @gmail.com. 
permission, arrests without warrant, monitoring of meeting and publication and establishment of curfews.

In Cameroon and South African legal systems, a presidential act is required to enforce a state of emergency or a state of siege ${ }^{1}$ in other words to legalise the introduction of violence within the legal sphere. However, the significant fact is that the legal and theoretical meanings of such an act seem to be different and lead to consequences on the rule of law and democratic principles. In the case of Cameroon, the presidential act declaring an emergency regime is an Act of State $^{2}$ whereas within the South African context, it is an Act of Parliament. ${ }^{3}$ An Act of State emanates directly from the president of the republic and is subject neither to parliamentarian approval nor to judicial review.

As of today there have been different developments of the concept of Act of State within Cameroon and South African contexts. In South Africa's apartheid legal system, there were various legal instruments similar to that of the modern Act of State called "ouster clauses." An example is contained in section 5B of the 1986 addition to the Public Safety Act ${ }^{4}$ which reads:

No interdict or other process shall be issue forth staying or setting aside any proclamation issued by the State President [...] and no court shall be competent to inquire into give judgment on the validity of any such proclamation, notice or regulation.

Unlike to South Africa, the concept of Act of State in Cameroon remains an entire part of the legacy of French colonialism in the country. ${ }^{5}$ For example section 22 of ordinance No $72 / 6$ of 26 August 1972 on the organisation of Supreme Court reads that "no court or tribunal is entitled to rule on acts of state." This provision recurred in section 4 of law No 2006/022 of 29 December 2006 on the organisation of the administrative courts which reads as follows:

No court is entitled to rule on acts of state.

1 Section 9 Law No 96/06 of 18 January 1996 to amend the constitution of 2 June 1972, section 2 (1) of law No 90/047 of 19 December 1990 on the state of emergency in Cameroon; section 37 of the Constitution of South Africa, 1996 (Act 108 of 1996), section 1 of the State of Emergency Act 64 of 1997.

2 See Kouang Guillaume, Charles contre Etat du Cameroun jugement No66 ADD/CS/CA du 31 Mai 1979.

3 Section 37 (1) of the Constitution of South Africa, 1996 (Act 108 of 1996).

4 No 3 of 1953.

5 This concept was developed by the French jurisprudence. See Conseil d'Etat 1 Mai 1822, Laffite: In this case, Mr Lafitte, a Banquer who had been claiming money from Napoleon's family was dismissed by judges on the ground that the matter was a political issue to be settled by government. Further, Conseil d'Etat 9 Mai 1967, Duc d'Aumale: The Seizure of a book, hostile to the regime was qualified by the council of state as political acts above their competence. 
In the case of Kouang Guillaume Charles vs the State of Cameroon ${ }^{6}$ the administrative court points out the characteristics of an Act of state by ruling that "one refers to an Act of State when it is about a political matter of an exclusive governmental concern." The court went on to provide various categories of acts of state. These include inter alia those pertaining to the diplomatic relationships of the state with foreign countries, the governmental acts issued in its relationships with Parliament (promulgation of laws, convening or ending of parliamentary sessions) and presidential act convening the Electoral College ${ }^{7}$ as well as the presidential act declaring a state of emergency and so called state of siege.

Following the declaration of a state of emergency or a state of siege through an Act of State or an Act of Parliament, the state becomes "a space where fact is converted into law and law into fact, and where a threshold of undecidability is produced at the point where law and fact merge into each other." ${ }^{8}$ In addition, as I will soon portray, the presidential act declaring an emergency regime sometimes suspends the law not for the sake of preserving the nation's territorial integrity against some potential threat (real or alleged) but for that of protecting and maintaining the current regime.

What exactly amounts to emergency regimes within the contexts of Cameroon and South Africa and what are the mechanisms of their enforcement?

What is the ultimate purpose of the presidential act enforcing an emergency regime within the legal systems of Cameroon and South Africa?

The answer to these questions firstly requires the understanding of the doctrine of emergency and their mechanism of enforcement within the context of South Africa and Cameroon and secondly the rationale behind such doctrine.

\section{B. Understanding the Doctrine of Emergency and their Mechanism of Enforcement within the Context of South Africa and Cameroon}

In this section, I examine on the one hand the starting process of an emergency situation in South Africa which is subject to an Act of Parliament and on the other hand, similar process within the Cameroon context which requires an Act of State.

\section{The Enforcement of an Emergency Situation in South Africa requires an Act of Parliament}

A state of emergency is the only institution of emergency regimes available in South African legal system. The historical development of this phenomenon can be traced back to the Apartheid legal system. The first state of emergency was declared by the apartheid state on 30 March 1960 as it is currently reported that 'in 1960 the emergency was imposed so

6 Guillaume, note 2.

7 Ibid.

8 Giorgio Agamben, State of exception, Chicago 2005, p.29. 
that the state could implement its apartheid policies. ${ }^{9}$ This policy was later confirmed on 20 July 1985, following national claims when former President Botha announced that violence in the country showed that: "ordinary law and order were inadequate." He then declared a state of emergency in thirty-six districts within the country. 2436 people were detained under the Internal Security Act. ${ }^{10}$ A further enforcement of a state of emergency in South Africa of historical importance happened on 12 June 1986 in the framework of the commemoration of the $10^{\text {th }}$ anniversary of the slaughter of Soweto's children. The measures taken have never been broader or more draconian than in the past. Curfews were imposed and even political funerals were forbidden. After 12 June the press was not allowed to print any incidences relating to political unrest. ${ }^{11}$ By 11 December newspapers were prohibited from printing non-governmental accounts of the police or the army activities; this went on to cover boycotts and any information relating to civil unrest and detentions. ${ }^{12}$ The government censorship of the press monitored publication of any information related to "unrest activities." 13

Since the advent of democracy in 1994 a state of emergency has never been tested in the country. Moreover the institution has been entirely redesigned to avoid abuses of the past. It is currently subject to constitutional as well as legislative restrictions. With regard to constitutional sources, a state of emergency is organised by section 37 of the Constitution of the Republic 1996, (Act No 108 of 1996). The first paragraph of this section reads:

A state of emergency may be declared only in terms of an Act of Parliament, and only when

(a) the life of the nation is threatened by war, invasion, general insurrection, disorder, natural disaster or other public emergency; and

(b) the declaration is necessary to restore peace and order.

Concerning the legislative sources, a state of emergency is regulated by the State of Emergency Act, 1997 "to provide for the declaration of a state of emergency; to empower the president to make regulations in pursuance of any declaration; and to provide for matters connected therewith." 14

Unlike to Cameroon, where the president is the only authority involved in the declaration of a state of emergency and so called state of siege, in South Africa, "a state of emergency may be declared only in terms of an Act of Parliament." The constitution has clarified the purpose of an Act of Parliament in section 41 (2):

9 South African history online, States of Emergency in South Africa: the 1960s and 1980s http://ww w.sahistory.org.za/topic/state-emergency-south-africa-1960-and-1980s (last accessed on 3 April 2014).

10 'First state of emergency'<http://www.sahistory.org.za/pages/classroom/pages/projects/grade12/le sson18/07-first-state-emergency.htm $>$ (last accessed on 9 November 2009).

11 Ibid.

12 Ibid

13 Ibid.

14 State of Emergency Act, 1997. 
An Act of Parliament must

a. establish or provide for structures and institutions to promote and facilitate intergovernmental relations; and

b. provide for appropriate mechanisms and procedures to facilitate settlement of intergovernmental disputes.

In light of this provision, it is evident that despite the emergency which might characterise a particular situation, the presidential act of declaration of a state of emergency in the country is to remain within the category of ordinary laws; which means an act enacted by the representatives of the people of South Africa. To validate the presidential intention to declare a state of emergency, parliament's members should follow a normal process and mechanisms of the enactment of laws and in case of disputes among them, the matter may be refers to judges. This conception to emergency regimes in South Africa is clearly identifiable to the conception developed by the tenants of the normative approach. This approach is the one including emergency regimes within the realm of law and affirms their compatibility with the doctrine of constitutional democracy. According to this conception, emergency regimes should be considered as part and parcel of the legal order. The popular belief is that emergency situations are first of all an executive affair. However to properly apprehend the substance of the normative conception to emergency regimes, it is crucial to highlight three points involving the role of different powers (executive, legislature and judiciary) in the management of crisis: Firstly, emergency regimes as an executive affair, secondly the necessity of parliamentary involvement in emergency regimes and thirdly the place granted to the judiciary.

The stand of emergency regimes as an executive affair considers these regimes to be a constitutional dictatorship. Proponents of this thought, which include Clinton Rossiter, claim that the institution of democracy contains heavy mechanisms which can work only under normal circumstances. According to this conception, the principle of constitutional dictatorship finds its rationale in the following postulate: Liberal democracy is complex, heavy and designed to function under normal circumstances and peaceful conditions. Accordingly it is not adaptable to crisis periods which require celerity. As contended by Rossiter:

Those republics which in time of danger cannot resort to a dictatorship will generally be ruined when grave occasions occur. ${ }^{15}$

The second argument of the normative conception to emergency regimes claims for the necessity of parliamentary involvement in time of crisis. The argument was developed in Albert Dicey's legality approach. The author states that in time of turmoil, priority should be given to parliament which remains the only authority to give carte blanche to officials when dealing with a threat. However, further reading between Dicey's lines reveals a flexi-

15 Clinton Rossiter, Constitutional dictatorship crisis government in the modern democracies, Princeton 1948 , title page. 
bility of the role granted to parliament. Then in case where there is not enough time to enact such an act, ministers ought to take every step, even at the peril of breaking the law, which is necessary either for restoring order or for repelling attack, and must rely for protection on parliament passing an Act of Indemnity. ${ }^{16}$

The third argument of the normative conception to emergency regimes prescribes an important place to be granted to the judiciary in the management of such regimes. The idea is echoed by David Dyzhenaus who rejects all conception of emergency which rely essentially on the suspension of law and the use of draconian measures by the executive power. As he argues, legality or the rule of law provides a legal constitution which is the basis of the authority of those who have power to make law. If they should stray outside the limits of that authority, they lack not only legal authority, but also any authority at all. ${ }^{17}$ Therefore suspending law and allowing for special powers are at the origin of what the author refers to as "legal black hole" and "legal grey hole."18 Dyzhenaus considers the former to be a legal vacuum and the latter as a situation with inefficient legal mechanisms. To cope with these issues, he suggests the adoption of what he calls the rule-of-law project which denotes the substantial role allowed to judges and the necessary cooperation between the executive and the legislative branch of government.

In light of these developments and looking at the South African context, it is evident that exceptional circumstances should not serve as a justification and absolute discharge absolving from non-compliance with pre-established rules and procedures. The presidential prerogative to declare a state of emergency in the country is then subject to restriction for this prerogative is placed under the direct supervision of parliament by law. As coined by the first paragraph of section 3 of the State of Emergency Act, 1997 "a copy of any proclamation declaring a state of emergency and of any regulation, order, rule or by law made in pursuance of any such declaration shall be laid upon the Table in Parliament by the President as soon as possible after the publication thereof." The role of parliament in emergency matter is very significant because not only should the deputies examine the presidential motive of the declaration of a state of emergency but they also have the power to disapprove or make any recommendation to the president in connection with the declaration. ${ }^{19}$ Parliament in the country is therefore invested with the constitutional right to supervise, validate and even disapprove the presidential act declaring a state of emergency. This prerogative enshrined in the constitution appears or at least claims to be a powerful guarantee against any authoritarian trend from the executive power. Indeed not only does the South African Parliament have a considerable influence in the validation of the presidential act declaring a

16 Albert Dicey, Introduction to the study of the law of the constitution ( $8^{\text {th }}$ edition) liberty fund, available at http://oll.libertyfund.org/title/1714, p.246 (last on accessed 25 April 2012).

17 David Dyzenhaus, The compulsion of legality, in: Victor Ramraj (ed.), Emergency and the limits of legality, Cambridge 2008, pp.33-59.

18 David Dyzenhaus, The constitution of law legality in a time of emergency, Cambridge 2006, p.3.

19 Section 3(2) of the State of Emergency Act, 1997. On the role of Parliament in emergency matter see section 37 (2) of the constitution as well. 
state of emergency, but also the Judiciary may rule on the opportunity and the validity of a state of emergency and any legislation enacted or any other action taken as a result of the declaration of a state of emergency. ${ }^{20}$ It is important to notice the close proximity of the South African emergency system with the principles developed by the normative conception to emergency regimes. On the one hand, the wide involvement of parliament recalls Dicey's concept of legality which advocate for Parliamentary involvement in the management of emergency situations. On the other hand, the role devolved to judges is in line with Dyzenhaus' thought. ${ }^{21}$

\section{The Enforcement of an Emergency Situation in Cameroon requires an Act of State}

Emergency regimes in Cameroon are framed by constitutional as well as legislative sources. These regimes are a legacy of French colonialism, and were introduced into the country's legal system to sustain harsh imperialist policies. In the context of colonialism and war of independence between French colonial authorities, their local acolytes and indigenous Cameroonians, a state of emergency played a key role in eliminating political challengers, increasing the powers of the executive, and absolving it of any accountability and responsibility. In so doing, draconian measures were regularly enforced when there was political agitation against colonialism, led by the Union des Populations du Cameroun (UPC), a nationalist movement started in April 1948 and led by Ruben Um Nyobe. The movement demanded nothing less than independence and reunification of the British and French Cameroons, a request acknowledged by two resolutions of the United Nations in January 1952 and December 1953, which required France's trusteeship in Cameroon to move toward autonomy or independence. ${ }^{22}$ On 19 February 1955, the French high commissioner in Cameroon, Roland Pre, issued a decree empowering all officials of the administration to "use force in order to prevent and disperse meetings that can disturb public order."23 Later in May 1959, Prime Minister Ahidjo, facing violence perpetrated by nationalist fighters and consequent insecurity issues, formally requested legal means to address the situation from the legislative assembly of Cameroon, (ALCAM) ${ }^{24}$ Such legal means were provided in four executive bills, which were approved by thirty-four to fourteen votes on 22 and 27 May 1959 through Law No 59/33 of 27 May 1959 on the maintenance of public order. ${ }^{25}$ For the first time legislation formally acknowledged two specific types of emergency regime, namely, a state of alert and a state of warning came into being. These two insti-

20 Section 37(3) of the Constitution, 1996 (Act 108 1996).

21 Even though Dyzhenaus' theory is posterior to the Constitution of South Africa.

22 Thomas Deltombe et al, Kamerun! Une guerre cachée aux origines de la Françafrique 1948-1971, Paris 2011, p.128.

23 Ibid p.163.

24 Abel Eyinga, Mandat d'arrêt pour cause d'élections: de la démocratie au Cameroun 1970-1978, Paris 1978, p.14.

25 Ibid. 
tutions gave legitimacy to the government's persecution of nationalist fighters, which had previously been carried out in secret. Special criminal tribunals were set up in Bafia, Douala, Dschang, Nkongsamba and Yaounde, and large numbers of suspects were arrested. Six opposition newspapers, including Bebey Eyidi's L'opinion au Cameroun, were suppressed. ${ }^{26}$ Following the so-called independence of Cameroon under French administration on 1 January 1960 emergency regimes appeared under section 20 of the constitution of 4 March 1960 and were renamed "state of emergency" and "state of exception". On 8 March 1960 Ahidjo decreed a state of emergency within eleven troubled divisions of the country for a period of four months, which was renewable indefinitely. ${ }^{27}$ Since then the practice has become a regular technique of government in the country.

With regard to constitutional sources, a state of emergency is provided by section 9(1) of law No 96/06 of 18 January 1996 to amend the constitution of 2 June 1972 which reads as follows:

The president of the republic may, where circumstances so warrant, declare by decree a state of emergency which shall confer upon him such special powers as may be provided for by law.

In addition to a state of emergency, there is another institution of emergency regimes in Cameroon which is a state of siege or so called l'état d'exception ${ }^{28}$ provided by the second paragraph of section 9 as follows:

In the event of a serious threat to the nation's territorial integrity or to its existence, its independence or institutions, the President of the Republic may declare a state of siege by decree and take any measures as he may deem necessary. He shall inform the Nation of his decision by message.

Concerning the legislative sources, a state of emergency is spell out by law No 90/047 of 19 December 1990. In light of these provisions, it is evident that the president in Cameroon is the only authority involved in the declaration of a state of emergency and so called state of siege. Such presidential act of declaration has the status of Act of State. As already emphasised, an Act of State in Cameroon refers to a presidential act belonging to the category of acts vested with political motive. The main characteristic of this act is its judicial immunity and as such it is neither subject to parliamentarian approval nor to judicial review.

This conception of Act of State in Cameroon is strongly connected to the critical conception to emergency regimes. According to the tenants of this conception, not only emer-

26 Nicodemus Awasom, Politics and constitution-making in Francophone Cameroon, 1959-1960, Africa Today 49 (2002), p.9-10.

27 Deltombe, note 22, p.387.

28 I have provided somewhere else a detail clarification about such incorrect formulation by the Cameroon law maker. See Gerard Emmanuel Kamdem Kamga, L'état d'exception and/or a state of siege: what is really wrong with section 9(2) of the Constitution of Cameroon?, Fundamina: A Journal of Legal History 19 (2013), pp.333-351. 
gency regimes are to be located beyond the sphere of law, but also they represent a political nihilism. To fully understand this development it is important to examine two ideas developed by the critical conception to emergency regimes. The first one was developed by Carl Schmitt who, through his doctrine of decisionism considers the exception to be the limit not only of law but of the whole doctrine of constitutional democracy. Starting from the reasoning that the state suspends the law in the exception on the basis of its right of selfpreservation, ${ }^{29}$ the author argues for a fundamental relation between politics and the limit. Schmitt advocates for a strong state that would ensure order, peace and stability. ${ }^{30}$ Following a "friend-enemy" distinction that is at the heart of the political, the author is convinced of the ever-present possibility of conflict within society and believes that only a resolute action can overcome the peril and ensure order and stability. ${ }^{31}$ Against "liberal normativism" that seeks to establish a theory of law that would be universally valid for all times and all situations, Schmitt posits that "all law is situational law." 32 The assumption that a state can ultimately rest on a set of mutually agreed-on procedures and rules that trump particular claims and necessities should not be considered. ${ }^{33}$ The occurrence of an exception is sufficient proof that law is unable to frame human life. The suspension of the ordinary legal normativity is performed on the basis that life can never be reduced or adequately understood by a set of rules, and all things considered, rule is of men and not of law. ${ }^{34}$ This explains why the author grants a major place to the concept of decision within the state:

\section{Like every other order, the legal order rests on a decision and not on a norm. ${ }^{35}$}

The second idea of the critical conception has been developed by Giorgio Agamben who portrays the state of exception as a situation of suspension of law in which application and norm reveal their separation. Accordingly, fact is converted into law and law into fact with both merging into each other. ${ }^{36}$ In Agamben's 2005 book State of exception, the author observes that if the state of exception is not to be included within the sphere of law, it is neither to be considered as an external phenomenon. This phenomenon is not to be perceived as a special kind of law such as the law of war but rather as a mechanism of suspension of the legal order itself. ${ }^{37}$ The state of exception rests on a legal void, human rights restrictions, and exceptional powers. As a result, the emptiness and standstill of the laws allows

29 Carl Schmitt, Political theology four chapters on the concept of sovereignty, Massachusetts 1985, p.12.

30 Ibid. p.xxiv.

31 Ibid. p. xvi.

32 Ibid. p.13.

33 Ibid. p.xvi.

34 Ibid. p.xx.

35 Ibid. p.10.

36 Giorgio Agamben, State of exception, Chicago 2005, p.6.

37 Ibid. p.4. 
for the combination of the extension of the military authority's wartime powers and the suspension of the constitution or of those constitutional norms that protect individual liberties. ${ }^{38}$

The rationale and praxis behind the concept of Act of State appears very clearly at this level. In his prerogative to enforce a state of emergency or a state of siege, the president in Cameroon acts as if the executive power was the only structure to rule the state. This is not new and this is not a Cameroonian peculiarity. Indeed the jurisprudence on the theory of Act of State during emergency regimes was formally established in 1962 by the French Conseil d'Etat in the case of Rubin de Servens. Following the Algiers Putsch in April 1961, French president Charles de Gaulle enforced section 16 of the French constitution on the state of exception which granted him full powers. The enforcement of section 16 lasted until 29 September 1961. On 3 May, despite the fact that the threat against the national integrity of France was over a long time ago, de Gaulle set up a special military tribunal for the trial of people who threatened the republic and infringed the discipline of the army. Ten officers of the army including Mr Rubin de Servens were sentenced by the military court. They then went to the Council of State to challenge the presidential decision of the creation of military tribunal on the ground of abuse of power. The judge argues about the presidential decision to implement section 16 of the constitution that it was an act of state and then the Council of State was not entitled to rule on neither the legality nor the control of the duration of implementation.

Later judicial decisions similar to that of the case of Rubin de Servens soon emerged in Cameroon where the jurisprudence of the Council of State and that of an Act of State is part of the legal arsenal. In 1992 for instance amidst the democratisation's wind over Africa and the deteriorating atmosphere characterised by political troubles and instability across the country, a presidential decree setting up an agenda for early presidential elections was issued. The judicial action before the court aiming at cancelling the decree was unsuccessful as the judge qualified the presidential decree to be an Act of State above his competence. Similarly, in 1995 the minister of youth and sports dissolved the Cameroon Football Federation (FECAFOOT). In answering a request of explanation from the FIFA (International Federation of Football Association), the minister replied that the act of dissolution of the federation was an Act of State and therefore not subject to accountability. ${ }^{39}$ From these two examples it appears that the notion of Act of State in Cameroon plays a central role in the local governance. The idea of Act of State is not only confined to the emergency sphere but it also extents to ordinary matters as the government may resort to it in denying any accountability and preventing its acts from being challenged. In addition since the amendment of the constitution in April 2008, the notion of Act of State in Cameroon has been expanded and constitutionalised. The irresponsibility of the president of the republic during and after his office is clearly entrenched in the new section 53(3) as follows:

38 Ibid. p.5.

39 Maurice Kamto, Le contentieux électoral au Cameroun, Lex Lata 20 (1995), p.8. 
Acts committed by the President of the Republic in pursuance of articles 5, 8, 9 and $10^{40}$ above shall be covered by immunity and he shall not be accountable for them after the exercise of his functions.

The Act of State in the country is a clear reference to the idea of raison d'état and as such remains a veil of irresponsibility and unaccountability of the president during and after his term. As a result, the legal regime and the status of a presidential act declaring a state of emergency or a state of siege espouses the ideas of Schmitt's decisionism: Sovereign is he who decides on the state of exception..$^{41}$ Declaring an emergency regime in Cameroon is therefore a matter of sovereignty, a presidential prerogative not to be challenged by anyone.

The notion of Act of State in the country is also in line with Agamben's approach of the state of exception as anomie. Through a unilateral declaration of emergency regimes and the impossibility of judicial review and parliamentary involvement, the president finds himself virtually in a situation where there is no norm except the one enacted by him.

\section{The Rationale behind the Doctrine of Emergency: Introducing the Violence within the Realm of Law}

Despite their legal and theoretical differences, the Act of State declaring an emergency regime in Cameroon and the Act of Parliament enforcing a state of emergency in South Africa aim to achieving a common task that is the introduction of violence within the realm of law. After all, emergency regimes are about law's suspension and human rights abuses without any possibility of compensation. In a state of emergency, violence is used by the government as the ultimate means of self-protection. This was the case in South Africa apartheid legal order and the current state in Cameroon. It is still unclear how the issue of violence can be reconciled with the mere idea of good and regulation. In his essay 'Critique of violence ${ }^{42}$ Walter Benjamin addresses the problem of the relation between law and justice as it hinges on violence. He questions whether violence in the social and political realms can be justified as a pure means in itself, independent of whether it is applied to just or unjust ends. ${ }^{43}$ Following an analysis of the legitimation of violence by the school of natural law and that of positive law, the author reached the conclusion that violence is to be considered as a basic component of the society with the sole purpose of protecting the law. According to him, any legal system is essentially defined by the relationship between means and ends, and then if violence is not an ethical or legal goal, it can only belong to the

40 These articles refer to the presidential prerogatives in general, such as the power of appointment (article 10), declaration of a state of emergency and a state of siege (article 9), representativeness (article 8) and general policy of the nation (article 5).

41 Schmitt, note 29, p.5.

42 Walter Benjamin, Critique of violence in: Matthew Calarco and Peter Atterton (eds.), The continental ethics reader, New York, London 2003, pp.113-126.

43 Ibid; p.155. 
realm of means as an effective force that aims to sanctioning violence, whatever its justification might be. ${ }^{44}$ For Benjamin the basic precept of any theory of violence is the following:

Just ends can be attained by justified means, justified means used for just ends. ${ }^{45}$

The state of emergency as currently experienced is nothing but violence against mankind. Such violence results from the fictitious character inherent to the current state of emergency 'in which we live' because a real state of emergency is the one that can deny the law and affirm the possibility of a human existence outside the law.

'Critique of violence' infers that a state of emergency has never been about protecting the freedom and human rights of the governed but to reaffirm the monopoly of the state as the sole and ultimate bearer of the use of violence. Whether referring to an Act of State in the case of Cameroon or to an Act of Parliament within the South African context, it is just a matter of procedures but the outcome remains the same: the use of violence as a means to achieving an end, in this case the normalisation of guilt and retribution, annihilation of human rights and reaffirmation of the state's supremacy over the governed. Violence remains the primary raw material which sustains the existence of the modern state:

When the consciousness of the latent presence of violence in a legal institution disappears, the institution falls into decay. ${ }^{46}$

Emergency regimes appear to be the materialisation of a law that has an 'interest in a monopoly of violence' that does not strive to protect any given just ends but the law itself. ${ }^{47}$ These institutions enforced through an Act of State or an Act of Parliament are yet to provide clear criteria of distinction between a state in turmoil and a regime under great stress. If within the context of post-apartheid South Africa a state of emergency remains to be tested, in Cameroon the normalisation of violence has made it difficult to distinguish between normality and crisis situations. ${ }^{48}$ Legalising violence in a state deemed democratic is nothing but a means to achieve an end in this case the preservation of power and the current politico system rooted in human rights abuses, reaffirmation of the executive's dominium over the state's structures.

44 Ibid.

45 Ibid. p.115; and p.122.

46 Ibid. p. 120.

47 Ibid. p. 117.

48 There is a combination between ordinary laws and extraordinary measures. For example on 04 April 2011, Cameroon parliament passed a bill empowering the president to enact "ordinances on the security of intelligence activities in Cameroon" and "on the use of intelligence's technologies in Cameroon." Following the provisions of this law, the president of the republic is entitled to request access to private emails, monitor the telephone traffic of people across the country, and waive the immunity of the elected parliamentarians at any time. 


\section{Conclusion}

The study aimed to analyse the act declaring an emergency regime in Cameroon and South Africa. It appears that the concept of emergency regimes varies depending on whether one is in Cameroon or in South Africa. The South African institutions rely on a single emergency system (a state of emergency) to address every sort of peril. On the contrary, there is more than one system of emergency regimes in Cameroon, which include a state of emergency and so called state of siege. In the country, the presidential act of declaration of a state of emergency or a state of siege is an Act of State invested with judicial immunity whereas in South Africa the act declaring a state of emergency is an Act of Parliament. The South African institutions provide for a parliamentarian as well as a judicial role in emergency matter, unlike to Cameroon where the president of the republic remains the only entity involved. In South Africa, declaring a state of emergency is a national concern unlike to Cameroon, where it is a presidential affair.

The idea of Act of State in Cameroon has not changed since the beginning of the colonial era whereas in South Africa the ouster clauses have been repealed following the advent of democracy in 1994. Despite these differences, the main similarity about the two countries remains: the legal incorporation of violence within the realm of law, a phenomenon which paradoxically keeps contradicting the law itself. The aim of these regimes irremediably leads to Benjamin's approach that considers violence as the basic component of the modern state, a means to achieve an end. 